Basrah Journal Of Surgery
Original Article

Bas J Surg, June, 26, 2020

\title{
DOES ANTICOAGULANT THROMBOPROPHYLAXIS INCREASE BLEEDING COMPLICATIONS IN SPINAL SURGERY AND SPINAL CORD INJURY? A SYSTEMATIC REVIEW AND META-ANALYSIS
}

\author{
Anh TV Nguyen*, Sonia Tran ${ }^{\circledR}$, Thamer Hamdan ${ }^{\#}$, Robin Turner \\ Ahmed-Ramadan Sadek ${ }^{\wedge}$, Darren Lui** \& Alexander S Montgomery!' \\ *MBChB, MRCS(Eng), PGDipSurgAnat, MSc(Orth Tr Sci), Orthopaedic registrar, Saint George's \\ University Hospitals, London, UK. ${ }^{a}$ BMed, MS (Surg Sci), Surgical registrar, The Children's Hospital at \\ Westmead, New South Wales, Australia. "FRCS, FRCP, FACS, FICS, American Board (Neuro Ortho) \\ Professor of Orthopaedic Surgery, Research fellow, Saint George's University Hospital, London, UK. \\ ${ }^{\$} \mathrm{PhD}$, MBiostat, Associate Professor and Director, Biostatistics Unit, University of Otago, Dunedin, New \\ Zealand. ^MBBS(Hons) BSc(Hons) DPhil.(Oxon), FRCS(SN), Spinal neurosurgeon, Department of \\ Spinal Surgery, Royal London Hospital, London, United Kingdom. ${ }^{* *}$ FRCS, Saint George's University \\ Hospital, London, UK. 'MBChB, MRCS(Eng), Dipl Orth(Eng), FRCS(Orth), Spinal surgeon and Clinical \\ Lead, Department of Spinal Surgery, Royal London Hospital, London, United Kingdom. \\ Investigation performed at the Department of Spinal Surgery, Royal London Hospital, London in conjunction with the Centre \\ for Biostatistics, Division of Health Sciences, University of Otago
}

\section{Abstract}

This study is a systematic review and meta-analysis. The routine use of anticoagulants for the prevention of venothromboembolism in spinal patients is controversial and the risk benefit analysis is poorly described. The objective of this study is to collate the current evidence and quantify the risk of bleeding associated with anticoagulant thrombophylaxis in the spinal patient, both in the elective and trauma settings.

Medline, Embase, Cochrane Trial Register databases and the grey literature were searched. Data were pooled via a meta-analysis from randomized trials and cohort studies comparing the rates of spinal epidural haematoma and wound haemorrhagic complications in spinal surgery patients receiving low molecular weight and low dose unfractionated heparin (LMWH/UFH) thromboprophylaxis and those not anticoagulated. The risk of bias within individual studies and across all the studies was assessed using the Cochrane risk of bias tools and the Grading of Recommendations Assessment, Development and Evaluation (GRADE) tool, respectively.

The meta-analysis included 10 studies of 96,042 patients with 1,007 relevant bleeding complications. A significant increase in the risk of extra-spinal wound haemorrhage was found in patients receiving peri-operative LMWH/UFH thromboprophylaxis compared to controls (OR $1.56,95 \% \mathrm{Cl} 1.18-2.06, \mathrm{p}=0.002, \mathrm{I} 2=8 \%$ ). The same comparison revealed no significant increase in the risk of spinal epidural haemorrhage (OR 1.20, 95\% Cl $0.65-2.22, p=0.56$, $12=0 \%$ ). The quality of evidence for both outcomes was low. There was insufficient data to conclude about the risk of haemorrhagic complications in spinal trauma and in patients receiving non-heparin thromboprophylaxis agents.

In conclusion, the results of this study raise concern about a possible increased risk of extraspinal wound haemorrhage associated with LMWH/LDUFH thromboprophylaxis in spinal surgery. Level of evidence: Therapeutic level III.

Key words: spine, surgery, spinal cord injury, trauma, thromboprophylaxis, anticoagulant, bleeding, epidural spinal haematoma, wound, complication

\section{Introduction}

$S_{\text {that low-molecular weight heparin or }}$ low dose unfractionated heparin (LMWH/LDUFH) be provided to spinal patients at risk of developing venothromboembolism

However, most spinal reluctant to use thromboprophylaxis , $^{2,10-17}$ perceived fear of
$(\mathrm{VTE})^{4-9}$ surgeons are anticoagulant due to a haemorrhagic 
complications in the spinal patient with potentially disastrous consequences. Whether such fear is warranted is unknown due to the paucity of the evidence $^{2,15,18-21}$. Recognizing such gap in the literature, the North American Spine Society $(\mathrm{NASS})^{2}$ recommend that a priority for future research be an evaluation of the bleeding risk associated with pharmacologic thromboprophylaxis use in spinal patients. Therefore, this systematic review and meta-analysis aim to determine the risk of spinal epidural haematoma (SEH) and extra-spinal wound haemorrhage associated with anticoagulant thromboprophylaxis in patients undergoing spinal surgery in both elective and trauma settings and in spinal trauma patients treated non-operatively. We anticipate the results will aid spinal surgeons in making an informed decision about the risk-benefit ratio of anticoagulant thromboprophylaxis use.

\section{Methods}

Data sources and collection: The search strategy included the following electronic databases; the Cochrane Central Register of Controlled Trials (Central), Medline via PubMed and Embase via Ovid. Additional studies were identified by hand searching of relevant bibliographies and journal archives and a search of the grey literature.

Eligibility criteria: Studies were eligible if they reported the number of SEH and wound haemorrhage complications in patients who received pharmacologic thromboprophylaxis (intervention group) versus those who did not (control group). Study designs included were randomised controlled trials (RCTs), quasi-RCTs, cohort studies and case control studies. Eligible patient populations were adult patients (>16 years) undergoing any spinal surgeries via any surgical approach or patients with acute spinal injuries (with or without spinal cord injuries (SCI)) that were treated operatively or nonoperatively. Studies were excluded if they were case reports, case series and audits, pertained to needle-based anaesthetic procedures or spontaneous bleeding events or of patients with pre-existing bleeding disorders. Studies were not excluded based on length of follow-up, language, publication status or dates. Regarding intervention, pharmacologic thromboprophylaxis referred to any chemical thrombo-prophylactic agent (including but not limited to LMWH/LDUFH, delivered by any route of administration, initiated at any time and for any duration). Any modality of mechanical thromboprophylaxis or placebo was eligible as control. Outcomes of interest were the number of patients with SEH or wound haemorrhagic complications that were associated with neurological symptoms or required treatment, including either operative or non-operative intervention.

Data synthesis and analysis: Following the Preferred Reporting Items for Systematic Reviews and Meta-Analyses (PRISMA) guidelines, two authors (A Nguyen and S Tran) performed all phases of this systematic review and metaanalysis in an independent and blinded manner. Disagreements were resolved either by consensus or consultation with the other authors who are a statistician and spinal surgery experts. Data extracted included study and participant characteristics, details of intervention and comparison methods, intra- and extraspinal bleeding (including wound and non-wound related) outcomes and details about any associated re-operation or treatment and mortality rates. The odd ratios (OR) of the number of patients with bleeding complications versus the number of patients without, between intervention and control groups, were pooled via a random-effect-model meta-analysis using the Review Manager (RevMan 5.3) ${ }^{22}$. For studies in which zero bleeding complication was observed in either the intervention or control group, a fixed value of 0.5 was added to the numerator. 
Forest plots were used to show the OR with 95\% confidence interval (CI) for each individual study and pooled across studies. Studies were weighted using the inverse variance method. Statistical heterogeneity was estimated using the I2 statistic.

Risk of bias within and across studies: Assessments of individual study quality were performed using the Cochrane Risk of Bias tool for randomised trials and the Risk Of Bias In Non-randomised Studies of Interventions (ROBINS-I) tool for observational studies ${ }^{23}$. The Grading of Recommendations

Assessment,
Development and Evaluation (GRADE) pro software was used to perform an assessment of the quality of the body of evidence across all studies. This assessment was based on the GRADE approach in which the quality of the evidence was judged to range between "no concern" to "very serious concern", according to five criteria: risk of bias, inconsistency, indirectedness, imprecision and publication bias $^{24,25}$.

\section{Results}

Study selection is presented via a PRISMA flow diagram in Figure 1.

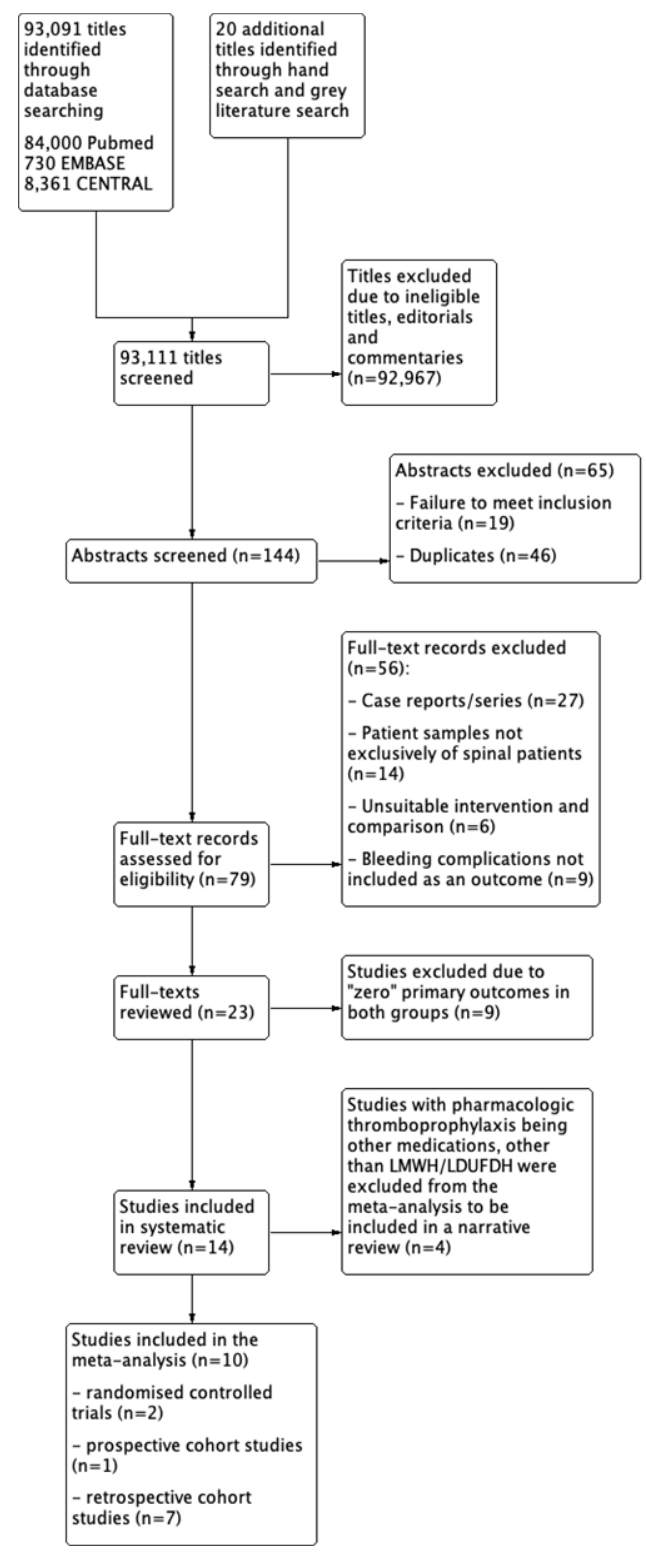

Figure 1: PRISMA flow diagram: study selection 
Study characteristics and risk of bias assessments are summarised in Table I, and Figures $2 \& 3$.

Table I. Summary table of characteristics of included studies

\begin{tabular}{|c|c|c|c|c|c|c|c|}
\hline \multirow[t]{2}{*}{ Study } & \multirow[t]{2}{*}{$\begin{array}{l}\text { Study } \\
\text { details } \\
\text { (type, origin, } \\
\text { follow up } \\
\text { duration) }\end{array}$} & \multirow{2}{*}{$\begin{array}{l}\text { Sample } \\
\text { size } \\
\text { Gender } \\
\text { proportion } \\
\text { (M/F) } \\
\text { Mean age } \\
\text { (years) }\end{array}$} & \multirow[t]{2}{*}{$\begin{array}{l}\text { Type of surgery \& } \\
\text { surgical approach }\end{array}$} & \multirow[t]{2}{*}{$\begin{array}{l}\text { Pharmacologic } \\
\text { prophylaxis } \\
\text { versus. } \\
\text { No pharmacologic } \\
\text { prophylaxis }\end{array}$} & \multicolumn{3}{|c|}{$\begin{array}{l}\text { Outcomes } \\
\text { Number of events in intervention } \\
\text { group (total): number of events in } \\
\text { control group } \\
\text { (p-value) }\end{array}$} \\
\hline & & & & & $\begin{array}{c}\text { Spinal epidural } \\
\text { haematoma (SEH) }\end{array}$ & $\begin{array}{r}\text { Extr } \\
\text { w } \\
\text { haei }\end{array}$ & $\begin{array}{l}\text {-spinal } \\
\text { und } \\
\text { atoma }\end{array}$ \\
\hline $\begin{array}{l}\text { Hamidi, } \\
2015\end{array}$ & $\begin{array}{l}\text { RCT } \\
\text { Iran } \\
10 \text { months }\end{array}$ & $\begin{array}{l}89 \\
46 \mathrm{M} / 43 \mathrm{~F} \\
52 \text { years }\end{array}$ & $\begin{array}{l}\text { Elective } \\
\text { instrumental } \\
\text { spinal surgery } \\
\text { NA }\end{array}$ & $\begin{array}{l}\text { Enoxaparin s.c. } 40 \\
\text { mg/day within } 12 \\
\text { hours preoperatively } \\
\text { vs. compression } \\
\text { stockings }\end{array}$ & nil & 0(40): & (49) \\
\hline Comment & \multicolumn{7}{|c|}{\begin{tabular}{l|l} 
One symptomatic haematoma that occurred in a patient post cervical anterior one- level discectomy, due to \\
laceration of external jugular vein. Re-operation was required
\end{tabular}} \\
\hline $\begin{array}{l}\text { Gruber, } \\
1984\end{array}$ & $\begin{array}{l}\text { RCT } \\
\text { Switzerland } \\
\text { NA }\end{array}$ & $\begin{array}{l}50 \\
\text { NA } \\
46 \text { years }\end{array}$ & $\begin{array}{l}\text { Herniated lumbar } \\
\text { disc surgery } \\
\text { NA }\end{array}$ & $\begin{array}{l}\text { Heparin-DHE } \\
\text { (2500IU sc.) twice } \\
\text { daily, commencing } \\
2 \mathrm{hrs} \text { preoperatively } \\
\text { for at least } 7 \text { days or } \\
\text { while inpatient vs. } \\
\text { placebo }\end{array}$ & nil & 0(25): & (25) \\
\hline Comment & \multicolumn{7}{|c|}{ In neither group was there early removal of stitches or operative revision of wound on post-operative day 4} \\
\hline $\begin{array}{l}\text { Green, } \\
1982\end{array}$ & $\begin{array}{l}\text { Quasi-RCT } \\
\text { USA } \\
\text { NA }\end{array}$ & 28 M / 4 F & $\begin{array}{l}\text { Acute SCI, } \\
\text { including patients } \\
\text { undergoing } \\
\text { surgery }\end{array}$ & $\begin{array}{l}\text { Aspirin } 300 \mathrm{mg} \text { bid, } \\
\text { and dipyridamole } 75 \\
\text { mg TDS and EPCC } \\
\text { vs EPCC }\end{array}$ & NA & 1(13): & (15) \\
\hline Comment & \multicolumn{7}{|c|}{ One patient who bled extensively during surgery and required a $1500 \mathrm{ml}$ transfusion } \\
\hline $\begin{array}{l}\text { Rokito, } \\
1996\end{array}$ & $\begin{array}{l}\text { Quasi-RCT } \\
\text { USA } \\
1 \text { year }\end{array}$ & $\begin{array}{l}110 \\
50 \mathrm{M} / 60 \mathrm{~F} \\
45 \text { years }\end{array}$ & $\begin{array}{l}\text { Spinal fusion } \\
\text { and/or } \\
\text { decompression } \\
\text { including a small } \\
\text { number of trauma } \\
\text { cases (unspecified } \\
\text { number) } \\
\text { Ant., post.\& comb. }\end{array}$ & $\begin{array}{l}\text { Warfarin (10mg on } \\
\text { the evening before } \\
\text { surgery) and TED vs. } \\
\text { TEDS+/-SCDs }\end{array}$ & nil & 2(35): & (75) \\
\hline Comment & \multicolumn{7}{|c|}{$\begin{array}{l}\text { Both patients with increased wound drainage, blood loss }>3 \mathrm{~L} \text { immediately post posterior spinal fusions for } \\
\text { scoliosis }\end{array}$} \\
\hline $\begin{array}{l}\text { Epstein, } \\
1981\end{array}$ & $\begin{array}{l}\text { Prospective } \\
\text { cohort } \\
\text { USA } \\
\text { NA } \\
\end{array}$ & $\begin{array}{l}121 \\
\text { NA } \\
\text { NA }\end{array}$ & SCI & $\begin{array}{l}\text { Heparin }(5,000 \text { IU SC } \\
\text { every } 12 \mathrm{hrs}) \text { versus } \\
\text { no prophylaxis }\end{array}$ & NA & NA & \\
\hline Comment & \multicolumn{7}{|c|}{ All bleeding was gastro-intestinal. All patients were given steroids $+/$ cimetidine $\&$ antacids concomitantly } \\
\hline $\begin{array}{l}\text { Cox, } \\
2014\end{array}$ & $\begin{array}{l}\text { Retrospective } \\
\text { cohort } \\
\text { USA } \\
\text { NA }\end{array}$ & $\begin{array}{l}1933 \\
1021 \mathrm{M} / \\
912 \mathrm{~F} \\
54 \text { years }\end{array}$ & $\begin{array}{l}\text { Elective and acute } \\
\text { surgery(fusion, } \\
\text { decompression, } \\
\text { vertebroplasty) } \\
\text { including for } \\
\text { spinal lesions }\end{array}$ & $\begin{array}{l}\text { LDUFH (5000IU s.c.) } \\
\text { tds, immediately pre- } \\
\text { /post-operative } \\
\text { throughout adm. } \\
\text { versus an old protocol } \\
\text { of chemo prophylaxis } \\
\text { commonly delayed } \\
\text { until }>24 \text { hours post- } \\
\text { operation }\end{array}$ & $\begin{array}{l}4(992): 6(941) \\
(p=0.538)\end{array}$ & NA & \\
\hline Comment & \multicolumn{7}{|c|}{ All SEH required surgical evacuation } \\
\hline $\begin{array}{l}\text { Dhillon, } \\
2017\end{array}$ & $\begin{array}{l}\text { Retrospective } \\
\text { cohort } \\
\text { USA } \\
30 \text { days }\end{array}$ & $\begin{array}{l}6869 \\
3676 \mathrm{M} \\
/ 3193 \mathrm{~F} \\
56 \text { years }\end{array}$ & $\begin{array}{l}\text { Cervical, thoracic } \\
\text { and lumbar } \\
\text { decompression, } \\
\text { fusion and staged } \\
\text { spine surgery }\end{array}$ & $\begin{array}{l}\text { LDUFH (5000IU s.c.), } \\
\text { LMWH ( } 40 \mathrm{mg} \text { of } \\
\text { enoxaparin, } 2500 \text { or } \\
5000 \mathrm{U} \text { of dalteparin, } \\
\text { or } 2.5 \mathrm{mg} \text { of } \\
\text { fondaparinux) } \\
\text { between } 1-3 \mathrm{~d} \text { after } \\
\text { surgery versus } \\
\text { mechan. prophylaxis }\end{array}$ & $\begin{array}{l}\text { 4(1904):9(4965) } \\
(p=0.6)\end{array}$ & $\begin{array}{l}5(1904 \\
(p=0.5\end{array}$ & 9(4965) \\
\hline Comment & \multicolumn{7}{|c|}{$\begin{array}{l}\text { Neurological deficits occurred in } 1 \text { of } 4 \text { patients in the chemoprophylaxis group and } 7 \text { of } 9 \text { patients in the } \\
\text { group not receiving chemoprophylaxis. Hemorrhagic complications occurred on postoperative day } 3-10\end{array}$} \\
\hline
\end{tabular}




\begin{tabular}{|c|c|c|c|c|c|c|}
\hline $\begin{array}{l}\text { Zeng, } \\
2017\end{array}$ & $\begin{array}{l}\text { Retrospective } \\
\text { cohort } \\
\text { China } \\
\text { NA }\end{array}$ & $\begin{array}{l}1761 \\
929 \mathrm{M}: \\
832 \mathrm{~F} \\
\text { NA }\end{array}$ & $\begin{array}{l}\text { Spine surgery } \\
\text { including spinal } \\
\text { deformity correction } \\
\text { Anterior, posterior } \\
\text { and combined } \\
\end{array}$ & $\begin{array}{l}\text { LMWH daily, } 4-8 \text { hours after } \\
\text { spine surgery until mobile versus } \\
\text { no LMWH }\end{array}$ & $\begin{array}{l}7(947) \\
\text { vs.0(814) } \\
(p=0.01)\end{array}$ & $\begin{array}{l}11(947): \\
6(814) \\
(p=0.36)\end{array}$ \\
\hline Comment & \multicolumn{6}{|c|}{6 of 7 SEH were symptomatic and surgically evacuated } \\
\hline $\begin{array}{l}\text { Cunningham, } \\
2011\end{array}$ & $\begin{array}{l}\text { Retrospective } \\
\text { cohort } \\
\text { Canada } \\
3 \text { months }\end{array}$ & $\begin{array}{l}3870 \\
\text { NA } \\
\text { NA }\end{array}$ & $\begin{array}{l}\text { Elective spinal } \\
\text { procedures ( } \\
\text { not specified) }\end{array}$ & $\begin{array}{l}\text { Pre-operative LDUFH } 5000 \text { units } \\
\text { subcutaneously versus no } \\
\text { prophylaxis }\end{array}$ & $\begin{array}{l}\text { 7/1428: } \\
\text { 9/2442 }\end{array}$ & NA \\
\hline Comment & \multicolumn{6}{|c|}{$\begin{array}{l}4 \text { SEHs presented with pain only, } 8 \text { SEHs presented with a motor deficit.2 SEHs were discharged with a neurologic } \\
\text { deficit, one of which was a C } 6 \text { quadriplegic, and the other walking with a walking frame and requiring a urinary } \\
\text { catheter. }\end{array}$} \\
\hline $\begin{array}{l}\text { Sharpe, } \\
2017\end{array}$ & $\begin{array}{l}\text { Retrospective } \\
\text { cohort } \\
\text { USA } \\
\text { NA }\end{array}$ & $\begin{array}{l}705 \\
508 \mathrm{M} / \\
197 \mathrm{~F} \\
45 \\
\text { years }\end{array}$ & $\begin{array}{l}\text { Operative } \\
\text { stabilization for blunt } \\
\text { spine fractures } \\
\text { (including SCI) } \\
\text { Anterior }(45 \%) \text {, } \\
\text { posterior }(51 \%) \text {, or } \\
\text { circumferential }(4 \%) \\
\end{array}$ & $\begin{array}{l}\text { Patients receiving more than } \\
50 \% \text { of scheduled preoperative } \\
\text { LDUFH or LMWH or "heparin } \\
\text { drip", within } 24 \text { hours of operative } \\
\text { fixation vs. no preoperative anti- } \\
\text { coagulation or less than } 50 \% \text { of } \\
\text { above scheduled preoperative dose }\end{array}$ & nil & $\begin{array}{l}6(288): \\
12(417)\end{array}$ \\
\hline Comment & \multicolumn{6}{|c|}{ All bleeding complications were all wound haematoma or infection, that requires treatment (antibiotics or drainage) } \\
\hline $\begin{array}{l}\text { Jacobs, } \\
2013\end{array}$ & $\begin{array}{l}\text { Retrospective } \\
\text { cohort } \\
\text { USA } \\
\text { NA }\end{array}$ & $\begin{array}{l}227 \\
133 \mathrm{M} / \\
94 \mathrm{~F} \\
49 \\
\text { years }\end{array}$ & $\begin{array}{l}\text { Major spinal surgery } \\
\text { for trauma (including } \\
\text { SCI) } \\
\text { Intervention group: } \\
\text { anterior } 21 \% \text {, } \\
\text { posterior } 71 \% \text {, } \\
\text { combined } 8 \% \\
\text { Control group: } \\
\text { anterior } 29 \% \text {, } \\
\text { posterior } 67 \% \text {, } \\
\text { combined } 2 \%\end{array}$ & $\begin{array}{l}\text { LDUFH/ LMWH (s.c. enoxaparin, } \\
\text { fondaparinux, or dalteparin) } \\
\text { within } 48 \text { hours of surgery vs. } \\
\text { TEDS/SCDs }\end{array}$ & Nil & $\begin{array}{l}\text { 10(56): } \\
3(171) \\
(0.35)\end{array}$ \\
\hline Comment & \multicolumn{6}{|c|}{ These draining hematomas required surgical debridement and irrigation } \\
\hline $\begin{array}{c}\text { Fang, } \\
2011\end{array}$ & $\begin{array}{l}\text { Retrospective } \\
\text { cohort } \\
\text { USA } \\
\text { 30 days }\end{array}$ & $\begin{array}{l}80,183 \\
36,775 \\
\text { M: } 43 \\
408 \mathrm{~F} \\
52 \\
\text { years }\end{array}$ & $\begin{array}{l}\text { Spinal fusion } \\
\text { Anterior, posterior } \\
\text { and combined }\end{array}$ & $\begin{array}{l}\text { Injectable heparin sodium }(5,000- \\
7,500 \text { units) or LMWH, within } 7 \text { - } \\
\text { days post-operatively Vs. } \\
\text { Mechanical prophylaxis alone or } \\
\text { no prophylaxis }\end{array}$ & NA & $\begin{array}{l}188(10450): \\
708(69733)\end{array}$ \\
\hline Comment & \multicolumn{6}{|c|}{ Details about the management of surgical site bleeding were not reported. } \\
\hline $\begin{array}{l}\text { Chunhong, } \\
2018\end{array}$ & $\begin{array}{l}\text { Retrospective } \\
\text { cohort } \\
\text { China } \\
\text { NA }\end{array}$ & $\begin{array}{l}87 \\
\text { NA } \\
\text { NA }\end{array}$ & $\begin{array}{l}\text { Thoracolumbar } \\
\text { fracture "with nerve } \\
\text { injury", treated with } \\
\text { pedicle screw fixation } \\
\text { Posterior approach }\end{array}$ & $\begin{array}{l}\text { Rivaroxaban (10mg) 6-10 hours } \\
\text { after operation within } 14 \text { days } \\
\text { after surgery vs. EPCC }\end{array}$ & nil & $\begin{array}{l}3(57) \text { vs. } \\
2(55)\end{array}$ \\
\hline Comment & \multicolumn{6}{|c|}{ Hemorrhagic complications occurred on post-operative day 1} \\
\hline $\begin{array}{l}\text { Silver, } \\
1974\end{array}$ & $\begin{array}{l}\text { Retrospective } \\
\text { cohort } \\
\text { UK } \\
\text { NA }\end{array}$ & $\begin{array}{l}110 \\
\text { NA } \\
\text { NA }\end{array}$ & SCI & $\begin{array}{l}\text { Phenindione (25-100mg daily) for } \\
12 \text { weeks, } 24 \text { hours post injury } \\
\text { Vs. no prophylaxis }\end{array}$ & NA & NA \\
\hline Comment & \multicolumn{6}{|c|}{ Gastrointestinal haemorrhage occurring between day 3 - week 8 post injury } \\
\hline $\begin{array}{l}\text { El Masri, } \\
1981\end{array}$ & $\begin{array}{l}\text { Retrospective } \\
\text { cohort } \\
\text { UK } \\
\text { NA } \\
\end{array}$ & $\begin{array}{l}102 \\
\text { all } \\
\text { male } \\
\text { NA }\end{array}$ & $\begin{array}{l}\text { SCI } \\
\text { Half of patients had } \\
\text { major associated } \\
\text { injuries }\end{array}$ & $\begin{array}{l}\text { Phenindione }(25-100 \mathrm{mg} \text { daily) for } \\
12 \text { weeks, } 24 \text { hours post injury vs. } \\
\text { no prophylaxis }\end{array}$ & NA & NA \\
\hline Comment & \multicolumn{6}{|c|}{$\begin{array}{l}\text { The only bleeding complication occurred in a } 73 \text {-year-old patient in the chemoprophylaxis group who died due to } \\
\text { bleeding peptic ulcer on day } 12 \text { post injury }\end{array}$} \\
\hline
\end{tabular}

Abbreviation: SEH: spinal epidural haematoma, s/c: subcutaneous; Heparin-DHE: heparin- dihydro-ergotamine; SCD: sequential compression device; TED: thromboelastic device; TDS: three times daily; LMWH: low molecular weight heparin; LDUFH: low dose unfractionated heparin; EPCC: external pneumatic calf compression; SCI: spinal cord injury; NA: (information) not available. Note: Refer to Appendix 2 for full table of characteristics of included studies 


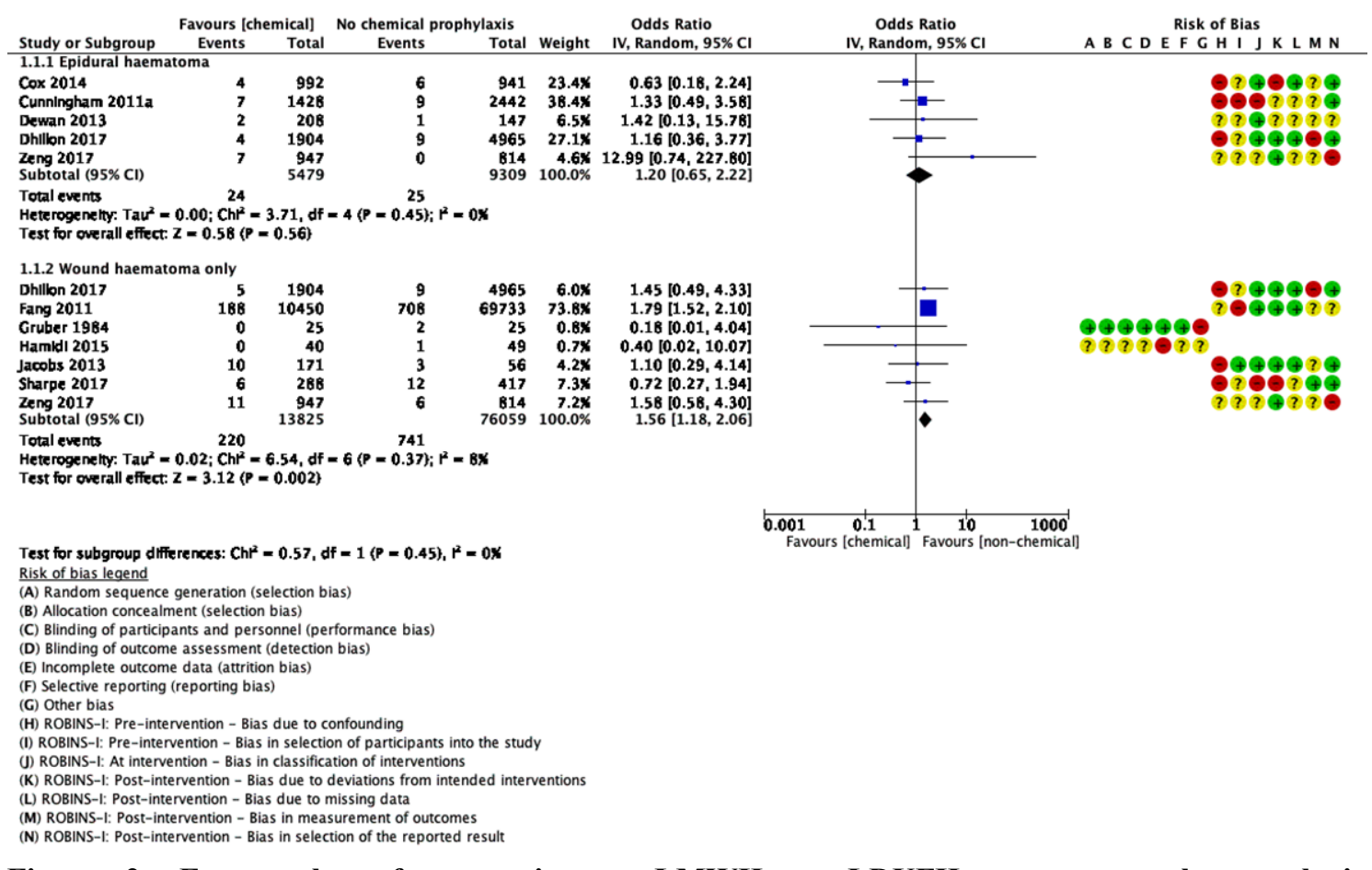

Figure 2: Forest plot of comparison: thromboprophylaxis

LMWH or LDUFH versus no pharmacologic

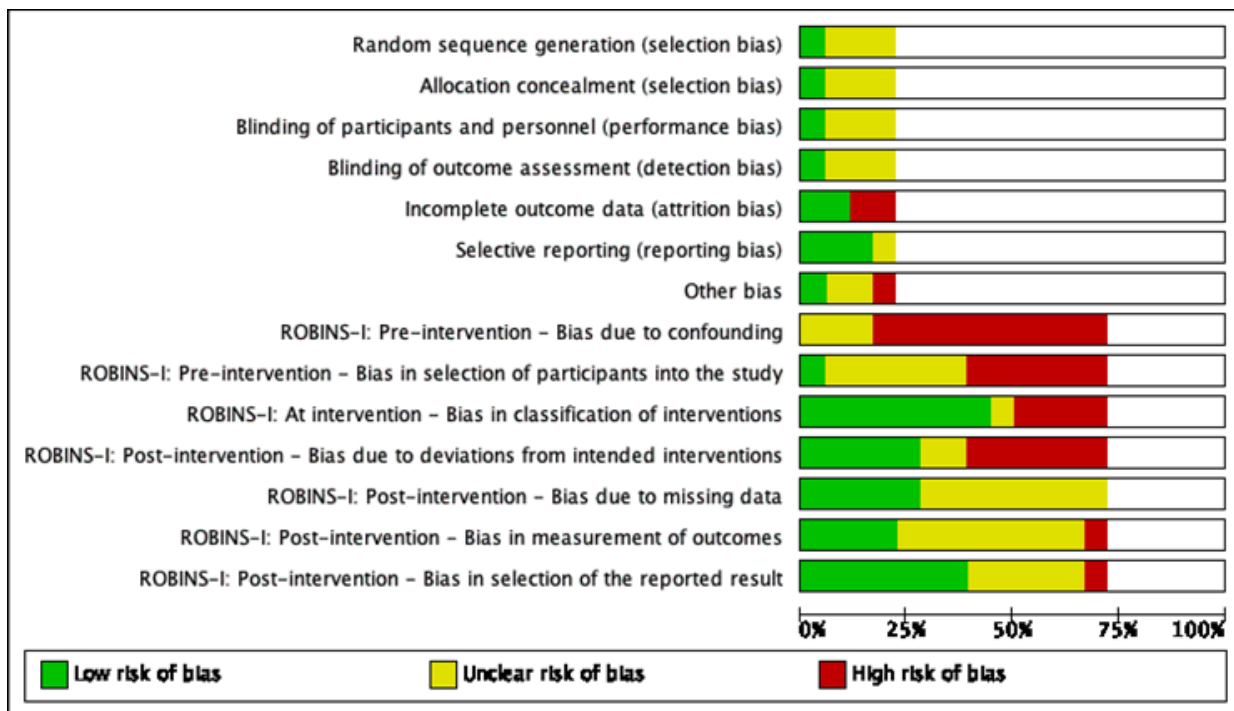

Figure 3: Risk of bias graph: review authors' judgements about each risk of bias item presented as percentages across all included studies.

A meta-analysis of 10 studies including 96,042 spinal surgery patients receiving thromboprophylaxis in the form of LMWH/LDUFH versus control revealed no fatal haemorrhage in either group. LMWH/LDUFH thromboprophylaxis was found to be associated with a $20 \%$ increase in the odds of SEH compared to controls but there was no evidence of an association. On the contrary, there was a strong association between the use
LMWH/LDUFH thromboprophylaxis and the $56 \%$ increase in risk of wound haemorrhages. Subgroup analysis did not demonstrate any difference in the ORs between the SEH and extra-spinal bleeding outcomes $\left(\mathrm{X}^{2}=0.57, \mathrm{p}=0.45\right)$ (Figure 2).

Sensitivity analysis revealed no significant difference in the results when randomised trials, studies of surgery on trauma patients and anticoagulant 
regimen other than LMWH exclusively were excluded.

Spinal epidural haematoma: There were five studies ${ }^{19,26-29}$ reporting 49 SEHs in 14,788 patients undergoing spinal surgery for elective indications and trauma. Two studies reported three patients who were discharged with persistent neurological deficits, a C6 quadriplegia, lower extremity weakness and bladder dysfunction $^{26,28}$. Three studies reported that the onset of most SEH events was within a week of surgery, ranging from day 1 to day 56 post operatively ${ }^{19,27,28}$. Pooled analysis of the five studies demonstrated that SEH was found in $0.3 \%$ of all patients (49 in 14,788), with $0.2 \%$ (32 patients) required surgical evacuation and $0.1 \%$ (22 patients) with neurological deficits in both intervention and control groups. The LMWH/LDUFH group had a higher proportion of SEH compared to the control group, $0.4 \%$ (24 in 5,479 patients) vs. $0.3 \%$ (25 in 9,309) respectively. There was a $20 \%$ increase in the odds of SEH for those with LMWH/LDUFH prophylaxis compared to controls, OR 1.2 ( $95 \% \mathrm{CI}, 0.65$ to 2.22 , low heterogeneity $\mathrm{I} 2=0 \%$ ), but no evidence of an association $(\mathrm{p}=0.56)$ (Figure 2). The absolute effect is zero per 1,000 , i.e. no patient in 1,000 patients would have a SEH with LMWH/LDUFH thromboprophylaxis (3 in 1,000), compared to controls $(3$ in 1,000) (Table II). The quality of the evidence from the five contributing studies is judged as very low due to a very serious concern in the risk of bias and the imprecision of the cumulative data (Table II, Figures $3 \& 4$ ).

Table II: Summary of findings:

Quality of evidence rating for studies comparing spinal epidural haematoma and extras-spinal wound haematoma between spinal surgery patients receiving LMWH/LDUFH thromboprophylaxis compared to those receiving no chemical prophylaxis

Patient or population: spinal surgery

Setting: inpatients

Intervention: Low molecular weight heparin (LMWH) or low dose unfractionated heparin (LDUFH)

Comparison: no chemical prophylaxis

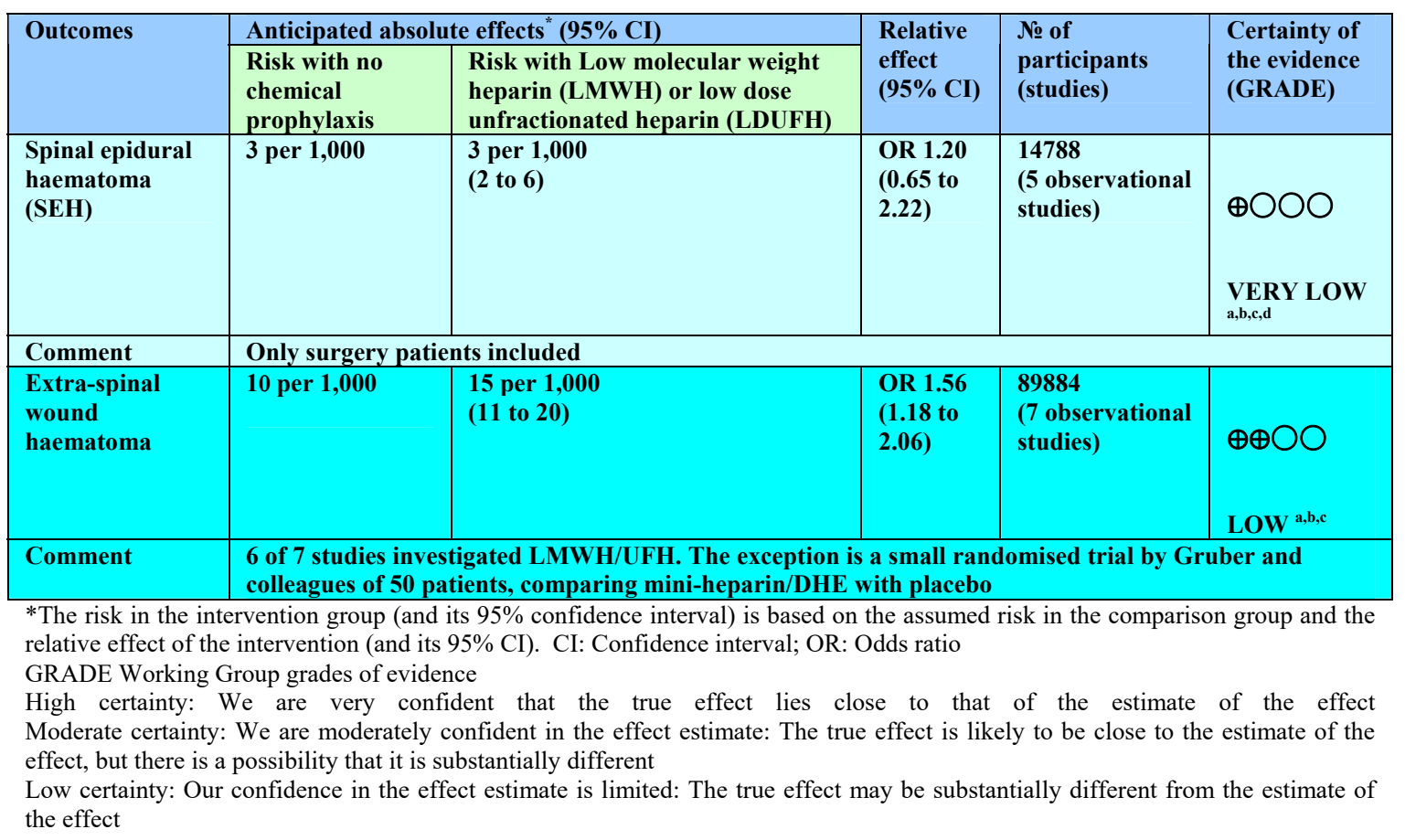


Very low certainty: We have very little confidence in the effect estimate: The true effect is likely to be substantially different from the estimate of effect

Explanations

a. Confounders not controlled for in observational studies, likely due to the fact that the outcome of interest is considered "secondary outcome" in most included studies

b. Selection bias (bias in selection of participants into the study) was a concern with the authors excluding certain patients based on participant characteristics observed after the start of intervention.

c. One of the randomized controlled trials did not report method of randomisation and allocation concealment

d. Wide confidence intervals containing RR of 1 (no effect) and appreciable benefit and harm (RR of 0.75 or 1.25) and/or small number of events, therefore "optimal information size" not met for the number of events

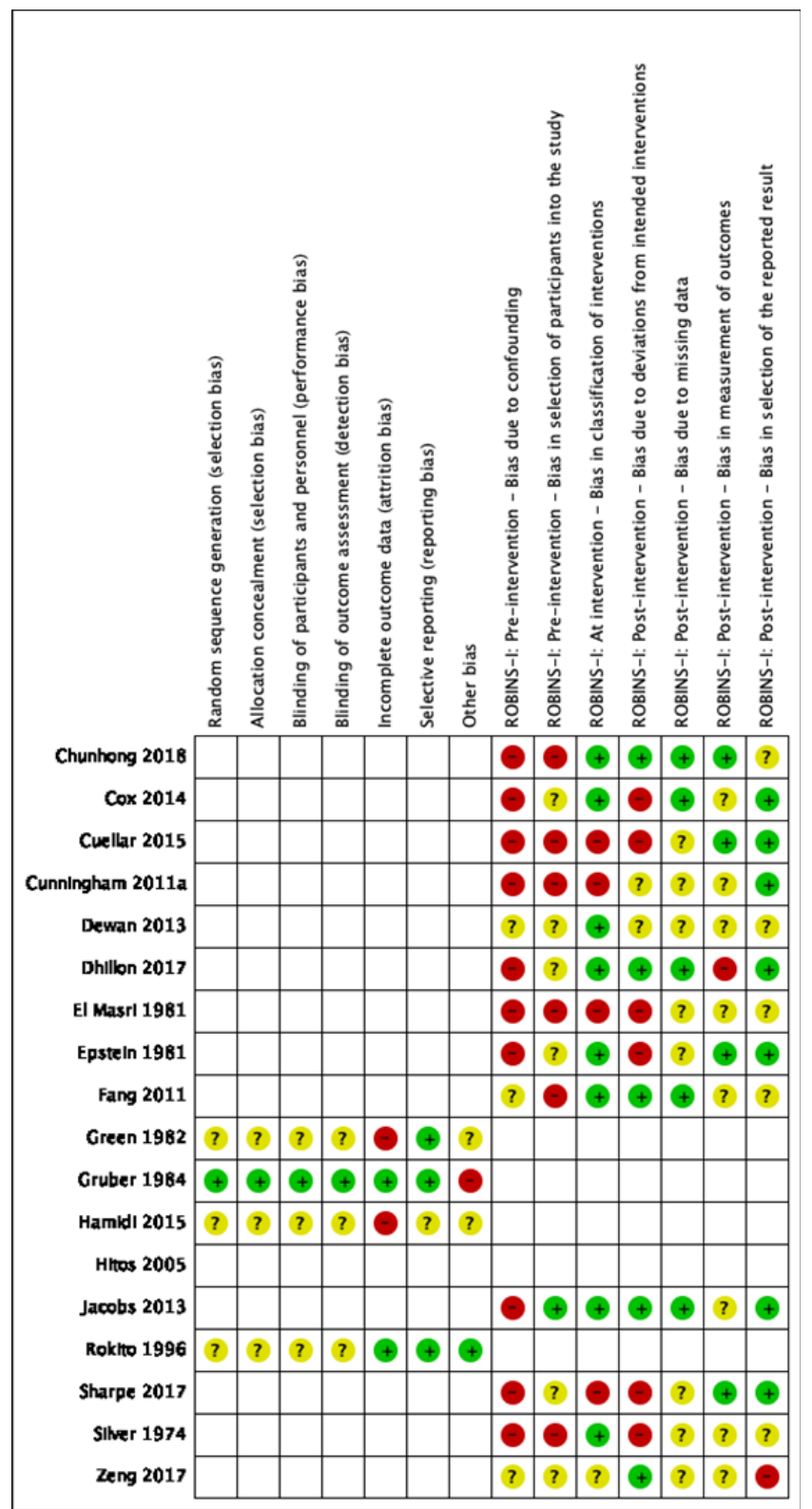

Figure 4: Risk of bias summary: review authors' judgements about each risk of bias item for each included study.

Extra-spinal wound haemorrhage: There are seven studies reporting 958 extraspinal wound haemorrhages in 89,884 patients undergoing spinal surgery. The pooled analysis found that $1.6 \%$ of patients receiving LMWH/LDUFH prophylaxis (220 in 13,825 patients) were complicated with wound haemorrhages, higher than the $1 \%$ proportion (739 in 76,059 patients) found in control patients. 
LMWH/LDUFH thromboprophylaxis was associated with a $56 \%$ increase in the risk of wound haemorrhages compared to controls, OR 1.56 (95\% CI, 1.18 to 2.06; low heterogeneity: $\mathrm{I} 2=8 \%$ ) and the evidence of an association was strong $(p=0.002)$ (Figure 2). The absolute effect was 5 per 1,000 , or 5 more patients would have a wound haemorrhage with LMWH/LDUFH thromboprophylaxis (15 in 1,000), compared to those not anticoagulated (10 in 1,000). The overall quality of the seven contributing studies was judged as low due to a very serious risk of bias in the included studies (Table II, Figures 3 \& 4).

Non-heparin thromboprophylaxis in spinal surgery

Warfarin: The only study investigating warfarin in the spinal population is a quasi-randomised trial ${ }^{30}$ that reported two patients in the warfarin group with excessive extra-spinal blood loss post spinal reconstruction (Table I). The study was of low quality with a small number of events, unclear details of randomisation, blinding processes and lack of statistical rigour.

Aspirin and dipyridamole: There is only one small quasi-randomised trial available in the spinal literature to-date of aspirin thromboprophylaxis in patients with spinal cord injuries, including some patients who underwent surgeries ${ }^{31}$. The authors reported one case of excessive intra-operative bleeding in the aspirin and dipyridamole group. No SEH complications were reported (Table I). The study was of poor quality due to unclear details regarding the randomisation process, blinding, measurement of bleeding outcomes and a lack of statistical rigour.

Rivaroxaban: Chunhong et $\mathrm{al}^{32}$ conducted a retrospective cohort study of 112 patients undergoing fixation for thoracolumbar fractures and found no difference in wound haematoma rates in a group of patients receiving rivaroxaban compared to those not anticoagulated
(Table I). No information regarding SEH was reported and the study has a critical risk of bias due to selection bias, missing data and selective reporting .

Spinal trauma: With regard to spinal trauma, the only study available in the literature to-date is one by Epstein et al of cervical, thoracic and lumbar spinal cord injured patients treated non-operatively ${ }^{33}$. The authors reported five gastrointestinal haemorrhages requiring transfusion in 32 patients of the LDUFH group and 19 in 89 patients of the control group (OR 0.68 , $95 \%$ CI $0.23-2.01)$. No SEH or wound complications were reported. The study has a critical risk of bias due to the unadjusted use of co-interventions and lack of reporting.

\section{Discussion}

Herein, we described the first and largest meta-analysis of pooled data in 96,042 spinal patients regarding the bleeding risk associated with anticoagulant thromboprophylaxis. Our results suggest that the use of LMWH/LDUFH thromboprophylaxis in spinal surgery does not associate with an increased risk of SEH, but is strongly associated with increased rates of extra-spinal wound haematoma. However, our certainty in the effect estimate is limited due to the low quality of the evidence.

Spinal epidural haematoma: Our results are consistent with four other reviews ${ }^{10,15,21,34}$ that reported a similarly small proportion of SEH in spinal surgery $(0.2-0.7 \%)^{34}$. These results suggest that spinal surgeons may have over-estimated the risk of post-operative SEH associated with LMWH/LDUFH thromboprophylaxis. A recent survey ${ }^{14}$ reported that $47 \%$ of spinal surgeons estimated this risk to be up to $5 \%$. Furthermore, we found no evidence that LMWH/LDUFH thromboprophylaxis was associated with an increase in the rate of SEH post spinal surgery. Glotzebecker et $\mathrm{al}^{15}$ came to the same conclusion in their narrative review. 
However, even though the risk of SEH seems negligible, this complication with the potential of permanent neurological deficits could translate to a morbidity burden that is greater than that of a nonfatal VTE event. Gould et $\mathrm{al}^{3}$ recommended that mechanical prophylaxis be used if the morbidity from a non-fatal bleeding event was believed to be at least two times more severe than those of a non-fatal VTE event.

Extra-spinal wound haemorrhage: No systematic reviews investigating this outcome are available for comparison. However, our data support the survey results of spinal surgeons ${ }^{16,35}$ of whom $25 \%$ noted an increase in post-operative wound complications in patients receiving LMWH thromboprophylaxis. In most patients undergoing elective spinal surgery via a posterior approach, excluding patients undergoing surgery for spinal cord injury, anticoagulant prophylaxis seems not justified because of its small VTE risk reduction benefit $^{10,36}$ due to a low estimated incidence $(0$ to $0.8 \%$ for $\mathrm{PE}$ and $1-6 \%$ for DVT $)^{10,21,34,37}$. Similarly, the mortality burden of VTE is estimated to be small, at $0.03 \%{ }^{38}$. From a VTE risk reduction point of view, the American College of Chest Physicians (ACCP) ${ }^{3}$ estimated that for patients with low VTE risk, the risk reduction of symptomatic events when using LDUH/LMWH thromboprophylaxis was similar to that of mechanical prophylaxis (5-6 per 1,000 patients). Therefore, the $\mathrm{ACCP}^{3}$ and $\mathrm{NASS}^{2}$ suggest that mechanical prophylaxis is preferred over LMWH/LDUFH for elective spinal surgery patients. Consistent with this suggestion, most North American spinal surgeons reported not using pharmacologic thromboprophylaxis in elective spine surgery setting ${ }^{16,39}$.

Nevertheless, the National Institute for Health and Care Excellence (NICE), NASS and $\mathrm{ACCP}^{1,2,20}$ recognise that a subgroup of spinal surgery patient carry a high risk of VTE (up to 6\%), therefore should be provided anticoagulant thromboprophylaxis ${ }^{40}$. The ACCP estimate that in the high-risk patient, thromboprophylaxis with LDUFH or LMWH has a risk reduction benefit of approximately 27 to 33 per 1,000 patients respectively. Comparing these figures with the estimated risk increase in SEH and wound haemorrhage from our metaanalysis $(0$ and 6 per 1,000 patients respectively), the benefit-risk ratio appears to favour anticoagulant thromboprophylaxis. However, how to select these high-risk patients for targeted thromboprophylaxis remains an unanswered question. Multiple authors $^{21,36,37,41}$ observed a high risk of VTE in surgery with prolonged duration, increased complexity and via the anterior or combined approach ${ }^{40,42}$. Apart from surgery related factors, patient specific risk factors include advanced age, spinal cord injury, polytrauma, neurological deficits, immobility, previous VTE, malignancy, hypercoagulable state and venous varicosity $3,17,41,43$. As a result, the $\mathrm{NASS}^{2}$ recommend that patients with the above high-risk factors be provided pharmacologic thromboprophylaxis. Consistent with this recommendation, a survey of 47 North American spinal surgeons ${ }^{16}$ revealed that all participating surgeons would use pharmacologic prophylaxis in patients after surgery for spinal trauma, anterior thoracolumbar surgery and in patients with spinal cord injury.

Non-heparin thromboprophylaxis in spinal surgery: The evidence regarding the safety and benefits of non-heparin thromboprophylaxis agents such as aspirin, warfarin and rivaroxaban in the spinal patient population is insufficient and our data did not add to this gap in the literature. However, we recommend that the NASS and ACCP revise their recommendation $^{2,3}$ that warfarin and aspirin be used as alternative thromboprophylaxis agents. As presented above, 
such statement is not consistent with the available evidence.

Spinal trauma: The ACCP, CSCIM, NICE and the AO Spine 1,34,45 $^{1,4 v i s e d}$ that all acute SCI patients should be provided routine pharmacologic thromboprophylaxis once there is no evidence of active bleeding. Such recommendation was formed on the basis of an estimated large risk reduction benefit ${ }^{20,46-48}$ of preventing four fatal PE per 1,000 patients treated and 10 times as many non-fatal VTE events as non-fatal bleeding complications ${ }^{3}$ when anticoagulant is used. Consistent with such recommendation, a recent survey reported a consensus amongst North American spinal surgeons in providing routine pharmacologic prophylaxis for all SCI patients ${ }^{16}$. Currently, LMWH is recommended as the preferred thromboprophylaxis agent over LDUFH due to superior efficacy ${ }^{20,44,48-50}$ despite a profound lack of evidence regarding bleeding risk of LMWH or any other anticoagulant thromboprophylaxis in this population. With regard to non-heparin based thromboprophylaxis in spinal cord injured patients, the evidence is scarce. Available in the literature are only two poorly conducted retrospective studies of the use of phenindione in 100 patients reporting inconclusive results ${ }^{9,51}$. The $\mathrm{CSCIM}^{44}$ recommend against the use of oral vitamin $\mathrm{K}$ antagonists such as phenindione in the acute treatment phase of SCI. The main limitation in this metaanalysis is that our certainty in the effect estimates is compromised by the low quality of the evidence of the included studies, most of which are retrospective cohort studies. However, high quality randomised trials with a large number of events in this topic are unlikely to be available in the near future due to costs and difficulty related to conducting strict randomisation in the spinal surgical and trauma population ${ }^{27}$.

With regard to future research, the optimal time frame of anticoagulant thromboprophylaxis administration, within which it is both safe and effective, needs to be investigated ${ }^{11,17,21,39}$. Currently, recommended time frames ${ }^{1,44,45}$ are not supported by robust evidence and often are too vague to be helpful in the clinical setting ${ }^{19,45,52}$.

\section{Conclusion}

Our results demonstrated no association between the use of LMWH/LDUFH thromboprophylaxis with increase in the risk of spinal epidural haematoma in patients undergoing spinal surgery. However, there was a strong association between the use LMWH/LDUFH thromboprophylaxis and the risk of wound haemorrhages. The overall quality of current evidence is low.

Acknowledgement: The authors appreciate the assistance of Professor John Fletcher in assisting us with locating his full-text article, Professor Kerry Hitos, Professor Enrique Ginzburg and Dr Margaret Fang who responded to our contact.

\section{References}

1.National Institute for Health and Clinical Excellence. Venous thromboembolism in over 16s: reducing the risk of hospital-acquired deep vein thrombosis or pulmonary embolism. NICE guideline (NG89)2018.

2.Bono CM, Watters WC, 3rd, Heggeness MH, Resnick DK, Shaffer WO, Baisden J, et al. An evidence-based clinical guideline for the use of antithrombotic therapies in spine surgery. The spine journal : official journal of the North American Spine Society. 2009;9(12):1046-51.

3.Gould MK, Garcia DA, Wren SM, Karanicolas PJ, Arcelus JI, Heit JA, et al. Prevention of VTE in nonorthopedic surgical patients: Antithrombotic Therapy and Prevention of Thrombosis, 9th ed: American College of Chest Physicians Evidence-Based Clinical Practice Guidelines. Chest. 2012;141(2 Suppl):e227S-e77S

4.Schizas C, Neumayer F, Kosmopoulos V. Incidence and management of pulmonary embolism following spinal surgery occurring while under chemical thromboprophylaxis. European Spine Journal. 2008;17(7):970-4.

5.Frim DM, Barker FG, 2nd, Poletti CE, Hamilton AJ. Postoperative low-dose heparin decreases thromboembolic complications in neurosurgical patients. Neurosurgery. 1992;30(6):830-2; discussion 2-3.

6. Wetzel N, Anderson MC, Shields TW. Pulmonary embolism as a cause of death in the neurosurgical patient. Journal of neurosurgery. 1960;17:664-8. 7.Tribe CR. Causes of Death in the Early and Late Stages of Paraplegia. Paraplegia. 1963;1:19-47.

8.Teasell RW, Hsieh JT, Aubut J-AL, Eng JJ, Krassioukov A, Tu L. Venous Thromboembolism After Spinal Cord Injury. Archives of Physical Medicine and Rehabilitation. 2009;90(2):232-45.

9.El Masri WS, Silver JR. Prophylactic anticoagulant therapy in patients with spinal cord injury. Paraplegia. 1981;19(6):334-42.

10.Mosenthal WP, Landy DC, Boyajian HH, Idowu OA, Shi LL, Ramos E, et al. Thromboprophylaxis in Spinal Surgery. Spine. 2018;43(8):E474-E81. 
11.Singh S, Haut ER, Brotman DJ, Sharma R, Chelladurai Y, Shermock KM, et al. Pharmacologic and Mechanical Prophylaxis of Venous Thromboembolism Among Special Populations. Rockville (MD); 2013.

12.Bryson DJ, Uzoigwe CE, Braybrooke J. Thromboprophylaxis in spinal surgery: a survey. Journal of Orthopaedic Surgery and Research 2012;7(14). 13.Jacobs LJ, Woods BI, Chen AF, Lunardini DJ, Hohl JB, Lee JY. Safety of thromboembolic chemoprophylaxis in spinal trauma patients requiring surgical stabilization. Spine. 2013;38(16):E1041-7.

14.Glotzbecker MP, Bono CM, Harris MB. Surgeon practices regarding postoperative thromboembolic prophylaxis after high- risk spinal surgery. Spine. 2008;33:2915-21.

15.Glotzbecker MP, Bono CM, Wood KB, Harris MB. Postoperative spinal epidural hematoma: a systematic review. Spine. 2010;35(10):E413-20. 16.Ploumis A, Ponnappan RK, Sarbello J, Dvorak M, Fehlings MG, Baron E, et al. Thromboprophylaxis in traumatic and elective spinal surgery: analysis of questionnaire response and current practice of spine trauma surgeons. Spine. 2010;35(3):323-9.

17.Hamidi S, Riazi M. Incidence of venous thromboembolic complications in instrumental spinal surgeries with preoperative chemoprophylaxis. Journal of Korean Neurosurgical Society. 2015;57(2):114-8.

18.Chang R, Scerbo MH, Schmitt KM, Adams SD, Choi TJ, Wade CE, et al. Early chemoprophylaxis is associated with decreased venous thromboembolism risk without concomitant increase in intraspinal hematoma expansion after traumatic spinal cord injury. The journal of trauma and acute care surgery. 2017;83(6):1088-94.

19.Dhillon ES, Khanna R, Cloney M, Roberts H, Cybulski GR, Koski TR, et al. Timing and risks of chemoprophylaxis after spinal surgery: a singlecenter experience with 6869 consecutive patients. Journal of Neurosurgery: Spine. 2017;27(6):681-93.

20.Geerts WH, Bergqvist D, Pineo GF, Heit JA, Samama CM, Lassen MR, et al. Prevention of Venous Thromboembolism: American College of Chest Physicians Evidence-Based Clinical Practice Guidelines (8th Edition). CHEST. 2008;133(6):381S-453S.

21.Cheng JS, Arnold PM, Anderson PA, Fischer D, Dettori JR. Anticoagulation risk in spine surgery. Spine. 2010;35(9 Suppl):S117-24.

22.The Cochrane Collaboration. Review Manager (RevMan). 5.3 ed. Copenhagen: The Nordic Cochrane Centre; 2014.

23.Sterne JA, Hernán MA, Reeves BC, Savović J, Berkman ND, Viswanathan M, et al. ROBINS-I: a tool for assessing risk of bias in non-randomised studies of interventions. BMJ. 2016;355.

24.Schünemann H, Brożek J, Guyatt G, Oxman A. The GRADE handbook published year 2013. Available from: http://gdt.guidelinedevelopment.org/app/handbook/handbook.html.

25.The Cochrane Consumers \& Communication Review Group. GRADE approach to evaluating the quality of evidence: a pathway 2017 [Available from: http://training.cochrane.org/path/grade-approach-evaluating-quality-evidence-pathway.

26.Zeng X-J, Peng H. Prevention of Thromboembolic Complications After Spine Surgery by the Use of Low-Molecular-Weight Heparin. World Neurosurgery. 2017;104:856-62.

27.Cox JB, Weaver KJ, Neal DW, Jacob RP, Hoh DJ. Decreased incidence of venous thromboembolism after spine surgery with early multimodal prophylaxis. Journal of Neurosurgery: Spine. 2014;21(4):677-84.

28.Cunningham JE, Swamy G, Thomas KC. Does preoperative DVT chemoprophylaxis in spinal surgery affect the incidence of thromboembolic complications and spinal epidural hematomas? Journal of spinal disorders \& techniques. 2011;24(4):E31-4.

29.Dewan MC, Godil SS, McGirt MJ. Mechanical vs Chemical Prophylaxis for Deep Venous Thrombosis in Patients Undergoing Lumbar Spinal Fusion: Comparative Effectiveness and Cost-Benefit. Neurosurgery. 2013;60:S158.

30.Rokito SE, Schwartz MC, Neuwirth MG. Deep vein thrombosis after major reconstructive spinal surgery. Spine. 1996;21(7):853-8; discussion 9.

31.Green D, Rossi EC, Yao JS, Flinn WR, Spies SM. Deep vein thrombosis in spinal cord injury: effect of prophylaxis with calf compression, aspirin, and dipyridamole. Paraplegia. 1982;20(4):227-34.

32.Chunhong L, Jin L, Qin Z, Guohui X. Anticoagulant effects of Rivaroxaban after surgical fixation of spinal fracture. Pakistan journal of pharmaceutical sciences. 2018;31(3(Special)):1131-5.

33.Epstein. N, Hood. D.C, Ransohoff. J. Gastrointestinal bleeding in patients with spinal cord trauma. Journal of neurosurgery. 1981;54(1):16-20.

34.Sansone JM, del Rio AM, Anderson PA. The Prevalence of and Specific Risk Factors for Venous Thromboembolic Disease Following Elective Spine Surgery. 2010;92(2):304-13.

35.Brooks F, Lau S, Baddour E, Rao P, Bhagat S, Ahuja S. Thromboprophylaxis in Spinal Surgery - Current UK Practice. 2013.

36.Fang MC, Maselli J, Lurie JD, Lindenauer PK, Pekow PS, Auerbach AD. Use and Outcomes of Venous Thromboembolism Prophylaxis after Spinal Fusion Surgery. Journal of thrombosis and haemostasis : JTH. 2011;9(7):1318-25.

37.Glotzbecker MP, Bono CM, Wood KB, Harris MB. Thromboembolic disease in spinal surgery: a systematic review. Spine. 2009;34(3):291-303

38.Smith JS, Fu K-MG, Polly JDW, Sansur CA, Berven SH, Broadstone PA, et al. Complication rates of three common spine procedures and rates of thromboembolism following spine surgery based on 108,419 procedures: a report from the Scoliosis Research Society Morbidity and Mortality Committee. Spine. 2010;35(24):2140-9.

39.Piran S, Bednar D, Drew B, Schulman S. Optimal timing of starting thromboprophylaxis for patients with acute spinal cord injury: A survey of Canadian spine surgeons. Thromb Res. 2017;160:38-40.

40.Dearborn JT, Hu SS, Tribus CB, Bradford DS. Thromboembolic complications after major thoracolumbar spine surgery. Spine. 1999;24(14):1471-6.

41.Nazareth A, D’Oro A, Liu JC, Schoell K, Heindel P, Jakoi A, et al. Risk Factors for Postoperative Venous Thromboembolic Events in Patients Undergoing Lumbar Spine Surgery. Global Spine Journal. 2018:2192568218797094.

42.Brambilla S, Ruosi C, La Maida GA, Caserta S. Prevention of venous thromboembolism in spinal surgery. European spine journal : official publication of the European Spine Society, the European Spinal Deformity Society, and the European Section of the Cervical Spine Research Society. 2004;13(1):1-8.

43.Oda T, Fuji T, Kato Y, Fujita S, Kanemitsu N. Deep venous thrombosis after posterior spinal surgery. Spine. 2000;25(22):2962-7.

44.Consortium for Spinal Cord Medicine. Prevention of Venous Thromboembolism in Individuals with Spinal Cord Injury: Clinical Practice Guidelines for Health Care Providers, 3rd ed. Topics in Spinal Cord Injury Rehabilitation. 2016;22(3):209-40.

45.Fehlings MG, Tetreault LA, Aarabi B, Anderson P, Arnold PM, Brodke DS, et al. A Clinical Practice Guideline for the Management of Patients With Acute Spinal Cord Injury: Recommendations on the Type and Timing of Anticoagulant Thromboprophylaxis. Global Spine Journal. 2017;7(3 suppl):212S-20S.

46.Velmahos GC, Kern J, Chan LS, Oder D, Murray JA, Shekelle P. Prevention of venous thromboembolism after injury: an evidence-based report-part II: analysis of risk factors and evaluation of the role of vena caval filters. The Journal of trauma. 2000;49(1):140-4.

47.Halim TA, Chhabra HS, Arora M, Kumar S. Pharmacological prophylaxis for deep vein thrombosis in acute spinal cord injury: an Indian perspective. Spinal cord. 2014;52(7):547-50

48.Agarwal NK, Mathur N. Deep vein thrombosis in acute spinal cord injury. Spinal cord. 2009;47:769.

49.Merli GJ, Herbison GJ, Ditunno JF, Weitz HH, Henzes JH, Park CH, et al. Deep vein thrombosis: prophylaxis in acute spinal cord injured patients. Arch Phys Med Rehabil. 1988;69(9):661-4.

50.Smith MD, Bressler EL, Lonstein JE, Winter R, Pinto MR, Denis F. Deep venous thrombosis and pulmonary embolism after major reconstructive operations on the spine. A prospective analysis of three hundred and seventeen patients. The Journal of bone and joint surgery American volume. 1994;76(7):980-5.

51.Silver JR. The prophylactic use of anticoagulant therapy in the prevention of pulmonary emboli in one hundred consecutive spinal injury patients. Paraplegia. 1974;12:188

52.Kim DY, Kobayashi L, Chang D, Fortlage D, Coimbra R. Early pharmacological venous thromboembolism prophylaxis is safe after operative fixation of traumatic spine fractures. Spine. 2015;40(5):299-304. 